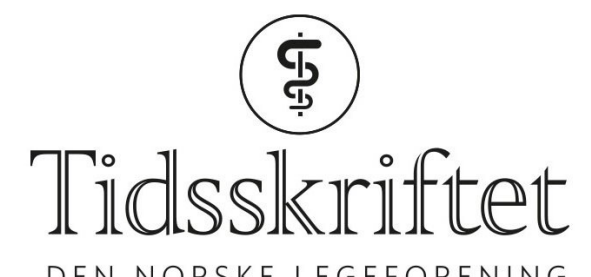

DEN NORSKE LEGEFORENING

\title{
Bidrar styringssystemet til gode prioriteringer?
}

LEGELIVET

BERIT BRINGEDAL

E-post: berit.bringedal@legeforeningen.no LEFO - Legeforskningsinstituttet

I atferdsøkonomien brukes begrepet «valgarkitektur» som navn på strukturer som danner skranker og føringer for de valg vi gjør.

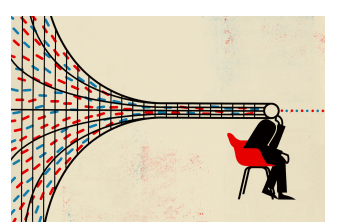

Illustrasjonsfoto: Mitch

Blunt/NTB scanpix

Valgarkitekturen kan være nettopp arkitektur, som når en bygningsstruktur inviterer til å ta trappen fremfor heisen. Den kan også være mindre konkret, som et regelverk, eller finansieringssystemer. Og den kan være enda mindre konkret, som en sosial kultur - men ikke mindre kraftfull av den grunn.

Hva kan vi si om valgarkitekturen i helsetjenesten? Hvordan virker den inn på de valgene de ulike aktørene fatter? I en nylig utgitt bok drøfter jurister, samfunnsvitere, leger og filosofer hvordan ulike styringsordninger virker inn på klinikernes prioriteringer for å kunne gi gode og likeverdige tjenester (1). Styringsordningene inkluderer lovverk, økonomisk styring (innsatsstyrt finansiering, DRG-systemet, Normaltariffen), kliniske retningslinjer og annen beslutningsstøtte, organisering og funksjonsdeling - og disse ordningene utgjør til sammen en vesentlig del av det vi kan kalle valgarkitekturen i helsetjenesten.

Boken dekker et vidt spekter, blant annet lover og forskrifter som styrer prioriteringer, hvilken betydning EUs pasientdirektiv kan få, legenes rapporter om hvordan styringssystemet påvirker de prioriteringene de gjør, i tillegg til teoretiske diskusjoner om profesjonsetikk, hva «likeverdige» tjenester innebærer og om sosial ulikhet og rettferdighet.

Basert på data fra Legepanelet ser vi at legene mener flere av styringsordningene bidrar positivt til å gjøre gode prioriteringer, ikke minst kliniske retningslinjer og pasientrettigheter. Innsatsstyrt finansiering i sykehus og rapporteringskrav, derimot, mener mange leger har negativ effekt: Over $30 \%$ sier dette har negativ innvirkning på mulighet til likebehandling, og over $40 \%$ mener det har negativ effekt på kvaliteten på tjenestene. Basert på intervjuer med klinikere i sykehus finner man også en bekymring for 
at økonomiske forhold får for stor betydning i sykehusene, med risiko for at det kan fortrenge andre viktige hensyn.

Om det å ta økonomiske hensyn er i strid med profesjonsetikken, drøftes i et eget kapittel. Prioritering er en innebygget del av klinikernes virksomhet, det er ikke mulig å unngå, hevder forfatteren. Derfor er det vesentlig å gjøre prioriteringer som ivaretar de profesjonsetiske dyder. Dette innebærer også å ta hensyn til kostnader. Uten dette, risikerer man at prioriteringene blir dårligere enn om man ikke hadde tatt hensyn til hva tiltakene koster.

Det er ikke helt klart hva man skal forstå med likebehandling, og heller ikke hva sosial rettferdighet innebærer. Dette diskuteres i to kapitler. I det ene argumenteres det for at sosial ulikhet $\mathrm{i}$ helse er urettferdig fordi det representerer en systematisk ulempe på mange områder med stor betydning for den enkeltes muligheter for å leve et godt liv - et perspektiv som får konsekvenser for hvilke tiltak som bør prioriteres for å utbedre ulikheten. I det andre argumenteres det for at likebehandling må ta utgangspunkt i den enkeltes mulighet til å få adekvat behandling, og det redegjøres for et bredt sett av potensielle barrierer mot dette. Fra et styringsperspektiv er det viktig å identifisere slike barrierer for å redusere ubegrunnet ulik tilgang.

Det manifeste styringssystemet, som myndighetene bruker bevisst for å påvirke beslutningstagerne, virker imidlertid ikke alltid som tiltenkt. Blant annet kan samvirket av ulike styringsverktøy få andre effekter enn faktorene hver for seg. Hvordan samspiller lovverket og de lokale strukturelle betingelsene? Støtter de finansielle insentivene opp om lovens formål eller anbefalingene i kliniske retningslinjer?

Samtidig med de manifeste styringsordningene virker også et latent system. Dette består av uintenderte og ofte uerkjente forhold som påvirker helsepersonellets valg.

Profesjonsetikken kan være én slik kultur, eller sosiale hierarkier med betydning for sosial aksept og anerkjennelse. Interessen, eller kanskje begeistringen, for ny teknologi kan være en slik latent faktor av stor betydning for prioriteringer.

Det er for få empiriske studier av hvordan styringssystemet faktisk virker på det som skjer i helsetjenesten. Vi vet litt om effekten av finansielle og juridiske virkemidler, og det eksisterer også enkelte studier av hvorvidt og hvordan leger følger retningslinjer. Det finnes imidlertid lite kunnskap om hvordan strukturelle forhold som organisering og funksjonsdeling virker inn på de valgene som gjøres eller den samlede effekten av ulike styringsfaktorer. Både teoretiske analyser og legenes selvrapportering er relevant kunnskap. Men det som særlig mangler nå, er gode empiriske studier av faktiske prioriteringer i norsk helsetjeneste og hvilken effekt valgarkitekturen har for å realisere målsetningene om gode og likeverdige tjenester.

LITTERATUR:

1. Aasen HS, Bringedal B, Bærøe K et al. Prioritering, styring og likebehandling. Utfordringer i norsk helsetjeneste. Oslo: Cappelen Damm Akademisk, 2018.

https://press.nordicopenaccess.no/index.php/noasp/catalog/book/33(20.8.2018).

Publisert: 17. september 2018. Tidsskr Nor Legeforen. DOI: 10.4045/tidsskr.18.0613

(C) Tidsskrift for Den norske legeforening 2020. Lastet ned fra tidsskriftet.no 